Розумовий розвиток, за Л. Занковим, може здійснюватися тільки в тих випадках, коли з боку тих, хто навчає, спеціально виявляється занепокоєння активним включенням свідомості в пізнавальну діяльність, коли не стільки отримання знань, скільки включення інтелекту в отримання відповіді стає основною метою навчання.

Самі ці особливості методики М. Зайцева не пояснені і до кінця не усвідомлені іiі автором.

Перетворення процесу навчання читанню із засобу на мету не тільки звільнило його від турбот про розвиток, але і об'єктивно зіткнуло його з тими, для кого найголовнішим було досягти усвідомлення ставлення дитини до предмета вивчення.

Яким би не був рівень розвитку свідомості у конкретної дитини, якщо іï достатньо для участі в грі, значить достатньо і для оволодіння будь-якою справою, будь-якими навичками, що пропонуються дитині в ігровій формі.

Навчання, яке будується на основі природовідповідності, забезпечує досягнення найвищих результатів, які не можливо досягти ніякою надприродною інтенсифікацією.

Сутнісна характеристика методу М. Зайцева полягає в тому, що він:

- значно скорочує термін навчання читання. За 3-4 заняття діти старшого віку починають читати, а через $2-25$ занять вони вже читають вільно, навіть не розуміють, коли навчились читати;

- забезпечує досягнення 100\% грамотності на письмі в подальшому навчанні;

- зберігає здоров'я дітей;

- має значний логопедичний вплив, ефективно впливає на розумовий розвиток.

Одна 3 головних особливостей методики М.Зайцева полягає в тому, що вона формалізована (на відміну від методик В. Шаталова і С. Лисенкової) i може бути застосована для широкого загалу, чого не скажеш про інші згадані методики.

Розглядувана методика певною мірою нівелює модель школи, де основним аспектом освіти є зміст інформації, яку треба передати учням, зосередженість на запам'ятовуванні, коли продукцією є факти, які запам'ятали учні. Освітні заклади, у яких навчальний процес здійснюється за такою моделлю, не здатні підготувати дитину до життя у XXI столітті.

1. Богуш А. М. Мовна підготовка дітей до школи / А. М. Богуш // Дошкільна лінгводидактика : хрестоматія : [навч. посіб. для студ. вищих пед. навч. закладів] / упоряд. А. М. Богуш . Ч.1 та 2. - К. : ВД «Слово», 2005. - С. 704-708. 2. Булдович М. Читати граючись. Кубики Зайцева. 3 досвіду роботи дитячого садка «Гармонія» / М. Булдович. - К. : Шкільний світ, 2009. - 128 с. - (Бібліотека «Шкільного світу»). 3. Журова Л. Є. Психологічні засади початкового навчання читання / Л. Є. Журова // Дошкільна лінгводидактика : хрестоматія : [навч. посіб. для студ. вищих пед. навч. закладів] / упоряд. А. М. Богуш. Ч.1 та 2. - К. : ВД «Слово», 2005. - С. 671673. 4. Турбовской Я. С. Игровое эмоциональоно-деятельностное обучение или теоретические основы методики Н.Зайцева / Я. С. Турбовской. - [Электронный ресурс]. - Режим доступа: http://www.metodikinz.ru/publ/?page=.sci.trubo\&dept=3.

УДК 366.632:378

І. Г. Максименко, кандидат пед. наук, доиент, О. Л. Пінська, кандидат пед. наук, доцент, Криворізький педагогічний інститут ДВНЗ «Криворізький начіональний університет»

\title{
ПІДГОТОВКА МАЙБУТНІХ ПЕДАГОГІВ ДО КОМУНІКАТИВНОЇ ДІЯЛЬНОСТІ В НАВЧАЛЬНОМУ ПРОЦЕСІ ВИЩОЇ ШКОЛИ
}

Максименко І. Г., Пінська О. Л. Підготовка майбутніх педагогів до комунікативної діяльності в навчальному процесі вищої школи.

У статті висвітлюється сутність комунікативної діяльності, розкривається технологія 
організації комунікативно спрямованого навчання як умови ефективної підготовки студентів до комунікативної діяльності.

Ключові слова: спілкування, діяльність, комунікативна діяльність, комунікативно спрямоване навчання.

Максименко $\quad$ I. Г., Пинская $\quad$ О. Л. Подготовка будущих педагогов $\quad$ к коммуникативной деятельности в учебном процессе высшей школы.

В статье освещается сущность коммуникативной деятельности, раскрывается технология организации коммуникативно направленного обучения как условия эффективной подготовки студентов к коммуникативной деятельности.

Ключевые слова: общение, деятельность, коммуникативная деятельность, коммуникативно направленное обучение.

Maksymenko I. G., Pinskaya O. L. Training future teachers communicative activities in the educational process of high school.

The essence of communicative activity, organization technique of communicative directed education as a condition of effective students' training to the communicative activity are disclosed in the article.

Key words: communication, activity, communicative activity, communicative directed education.

Сучасні демократичні перетворення в усіх сферах суспільства поставили перед вищою школою завдання переходу до особистісно-розвивальної моделі навчального співробітництва, де студентам відводиться активна роль суб' єктів пізнавальної діяльності. У Національній доктрині розвитку освіти України у XXI столітті серед пріоритетних напрямків реформування сучасної освіти наголошується на необхідності формування в майбутніх педагогів умінь міжособистісного спілкування та підготовки їх до життя в динамічному суспільстві. 3 огляду на це, важлива роль належить педагогічному спілкуванню як чиннику духовного, інтелектуального та емоційного розвитку особистості, гуманізації взаємин викладача зі студентами в навчально-виховному процесі. Відповідно до цього освітній процес у ВНЗ необхідно будувати так, щоб створювалися найбільш сприятливі умови для підготовки майбутніх педагогів до комунікативної діяльності.

Метою статті є висвітлення сутності комунікативної діяльності, характеристика технології організації комунікативно спрямованого навчання як умови ефективної підготовки студентів до комунікативної діяльності.

Феномен комунікативної діяльності за своїми виявами настільки різноаспектний, що $є$ предметом зацікавленості філософів, психологів, соціологів, педагогів. Теоретикометодологічним основам комунікативної діяльності присвячено роботи науковців Г. Андреєвої, О. Бодальова, В. Кан-Калика, О. Леонтьєва, Б. Ломова та ін. Проблеми підготовки майбутніх педагогів до комунікативної діяльності висвітлюються в працях Ю. Бабанського, С. Максименка, А. Петровсього та ін. Формування у майбутнього педагога індивідуального стилю комунікативної діяльності було предметом дослідження Я. Коломинського, О. Леонтьєва, Л. Петровської та ін. Шляхи комунікативної підготовки педагога висвітлено у дослідженнях Н. Бутенко, Н.Волкової, В. Кан-Калика, Я. Коломинського та ін.

Науковці зауважують, що процес підготовки майбутньою педагога до комунікативної діяльності має бути системою змістових, процесуальних параметрів педагогічної освіти та спеціальної організації освітнього середовища ВНЗ. Проте, вивчення практичного досвіду свідчить, що наявна система комунікативної підготовки майбутніх педагогів не повною мірою відповідає вимогам сьогодення.

Підготовка студентів до комунікативної діяльності потребує розкриття сутності комунікативної діяльності, що неможливо без установлення співвідношення понять «спілкування», і «діяльність». 
3 позиції діяльнісного підходу спілкування розглядається в двох аспектах: як атрибут (сторона) діяльності (О. Бодальов, В. Добрович, В. Кан-Калик, А. Киричук, Б. Ломов та ін.) і як самостійний вид суб'єкт-суб'єктної діяльності - комунікативної.

Спілкування як особливий вид комунікативної діяльності обгрунтовано у філософії М. Каганом, у психології Я. Коломинським, О. Леонтьєвим, В. М'ясищевим, А. Петровським та ін. Так, Я. Коломинський стверджує, що «спілкування - особливий вид діяльності, об'єктом якого є інша людина, предметом - iї внутрішній світ (почуття, прагнення, погляди, переконання, знання тощо), метою - зміни в цій картині світу, а засобами - вся сукупність інформаційних дій - мови, міміки, жестів. При цьому партнери є одночасно один для одного і об'єктами, і суб'єктами діяльності»[7, с. 46].

Спробу синтезувати різні підходи зробила Г. Андреєва, яка розглядає спілкування і як діяльність, і як продукт цієї діяльності [1, с. 95]. Зауважимо, що за наявності розбіжностей у поглядах, методологічна спільність їх виявляється в тому, що в них декларується позиція про єдність спілкування і діяльності, яка виявляється в наявності спільної якості бути відносно самостійними формами соціальної активності індивіда: діяльність - це активність, спрямована на перетворення об'єкта, а спілкування - це взаємодія, де об'єкт завжди суб'єкт, інакше немає взаємодії. Дійсно, немає діяльності поза спілкуванням, а спілкування характеризується всіма ознаками діяльності, за винятком діяльності, що здійснює саме людина, тобто коли сама людина є предметом діяльності.

У цій роботі провідним прийнято підхід, відповідно до якого спілкування розглядається як самостійна діяльність (комунікативна), яка має специфічні риси, що відрізняють ії від інших видів діяльності.

Розробляючи технологію підготовки студентів до комунікативної діяльності, ми спиралися на розроблену психологами теорію, згідно з якою психіка людини виявляється і формується тільки в діяльності, але не в будь-якій діяльності, а тільки в аналогічній тій, яка зумовлює появу необхідних властивостей. При цьому, ступінь сформованості діяльності залежить не стільки від іiі тривалості, скільки від характеру іiі організації, від особливостей запропонованої системи дій $[1 ; 3 ; 9 ; 12]$.

Оволодіння комунікативною діяльністю стане можливим тільки в процесі такого навчання, яке за своїми характеристиками відповідатиме комунікативній діяльності, організація якої потребує впровадження у традиційну систему навчання комунікативного методу, що робить весь процес навчання комунікативно спрямованим. Науковими дослідженнями (В. Гаркуша, Ю. Пасов, О. Татьянченко та ін.) доведено, що комунікативно спрямоване навчання - це навчання, під час якого спілкуванню навчаються у процесі діяльності спілкування. Тобто спілкування, виконуючи функції засобу й умови навчання, стає і його метою [8]. Якщо ми хочемо навчити студентів комунікативної діяльності, то вчити цього потрібно в умовах діяльності, яка за своїми характеристиками будується за зразком комунікативної діяльності, особливістю якої є суб'єкт-суб'ктна взаємодія, організована на основі співпраці. А це означає, що підготовка студентів до комунікативної діяльності визначається не тільки змістом, а, передовсім, формами і методами навчання.

Організацію співпраці забезпечує залучення студентів до різноманітних форм колективної і групової навчальної діяльності, які дозволяють у змодельованій ситуації відображати сутність процесів, що відбуваються у професійно-педагогічній діяльності.

Засвоєння студентами системи усвідомлених комунікативно-значущих знань, формування позитивного відношення до них здійснювалося на лекційних заняттях. Оскільки в умовах лекційних потоків організувати суцільний процес спілкування не видається можливим, щоб відійти від традиційної суб'єктно-об'єктної взаємодії, яка призводить до відсутності спілкування як такого, і підвищити комунікативну активність студентів, слід надавати перевагу проблемним лекціям та лекціям-бесідам.

Організація проблемного читання лекцій орієнтує викладача не тільки на свої потреби, але й на потреби та інтереси студентів, накопичення згоди, свободу виразу думки, яка 
вимагає індивідуального осмислення інформації, прагнення до творчості, імпровізаційності. Ми вважаємо, що проблемність лекції забезпечується використанням різноманітних прийомів: діалог у монолозі, створення інформаційного розриву; висловлення суперечливих думок; розв'язання комунікативних задач; виконання студентами окремих функцій викладача тощо. Ці прийоми забезпечують безпосередній контакт викладача 3 аудиторією, підтвердження студентських гіпотез, які допомагають оволодінню комунікативними знаннями і вміннями, що сприяє розвитку нестандартного мислення. Поєднання інформаційних, пошукових, дискусійних методів активізує діяльність усіх сфер особистості студента: когнітивну, емоційно-вольову, дієвоповедінкову, що розширює й поглиблює розуміння сутності комунікативної діяльності та створює можливість засвоїти не тільки зміст комунікативних понять, але й сформувати оцінні судження і готовність керуватися цими знаннями у практичній комунікативній діяльності.

Важливе значення у формуванні комунікативних умінь мають практичні заняття, структура яких вміщує актуалізацію опорних знань, формування умінь i навичок комунікативної діяльності

На першому етапі особливу увагу слід звертати на поглиблення, узагальнення й систематизацію знань, оволодіння процедурно-прагматичними знаннями, надання їм практичної спрямованості, показ значущості знань задля формування інтересу й потреби в оволодінні ними. Для цього доцільно використовувати метод бесіди як найбільш прийнятний, доступний за технологією і результативний як за часом, так і за можливістю активізації комунікативної активності студентів. Можна практикувати і виступ студентів 3 окремих питань із доповідями, рефератами з їх подальшим обговоренням.

На другому етапі здійснюється формування комунікаивних навичок. Спочатку студенти оволодівають окремими діями, що характеризують цю навичку, потім на системі вправ відпрацьовується навичка цілісного використання комплексу дій та їх самостійного використання у стандартних ситуаціях. Односторонній і категоричний інструктаж, показ зразка виконання дії і контроль за ступенем його репродуктивного відтворення сприяє ефективному формуванню комунікативних навичок.

Третій етап спрямований на формування умінь переносити навички в нові ситуації, що потребує: 1) створення уявної моделі комунікативної дії; 2) вибір адекватного уявній моделі практичного способу дії. Уявна модель комунікативної дії створювалася у процесі розв'язання педагогічних задач, які у психолого-педагогічній літературі розглядаються як поєднувальна ланка між теоретичними знаннями і практичними уміннями.

Розв'язання педагогічних задач потребує осмислення педагогічної ситуації, що склалася, і визначення педагогічної й комунікативної задачі. Для створення уявної моделі дії необхідно виходити з того, що «комунікативна задача є тією ж педагогічною задачею, але перекладеною на мову комунікації. Комунікативна задача відображає педагогічну, але має щодо неї допоміжний, інструментальний характер» [6, с. 85]. Розв'язання комунікативних задач здійснюєвалося за таким планом: 1) визначення і формулювання проблеми; 2) аналіз фактів, відображених у проблемі; 3) підбір критеріїв для оцінки рішення; 4) оцінка рішення; 5) побудова уявної моделі способу дії; 6) розв'язання проблеми.

Для розв'язання комунікативних задач студентам доцільно пропонувати ситуації двох видів: завершені і незавершені. Під час розгляду ситуацій першого типу студенти повинні здійснювати: 1) аналіз й аргументовану оцінку комунікативних дій учасників ситуації; 2)діагностування можливих наслідків виконуваних ними дій.

Розв'язання незавершених педагогічних ситуацій здійснюється поетапно: 1) аналіз, що передбачає діагностику суб' єктно-об'єктних і суб'єктно-суб' єктних відносин, які склалися в конкретних умовах цієї ситуації; 2) визначення мети дії, що перетворює ситуацію на педагогічну задачу; 3) визначення комунікативного забезпечення (вибір адекватних ситуації і особливостям учасників спілкування вербальних і невербальних засобів); 
4) передбачення утруднень, які можуть виникнути в контексті розв'язання цієї задачі; 5) створення уявної моделі комунікативної дії, адекватної ситуації і особливостям ії учасників; 6) розв'язання комунікативної задачі; 7) аналіз ефективності прийнятого рішення.

Навчаючи студентів розв'язанню таких задач, необхідно акцентувати увагу на таких положеннях: кожна задача має свій прихований підтекст, детермінований мотивами поведінки суб'єкта і об'єкта комунікативної взаємодії; у кожній задачі завжди відсутні певні дані, що створює можливості для багатоваріативності рішень; під час розв'язання відсутня можливість урахувати всі чинники (соціальні, індивідуально-психологічні, ситуативні), а тому кожне розв'язання тільки відносно можна вважати закінченим; задачі містять умови для подальшого вдосконалення методики їх вирішення.

У процесі розв'язання комунікативних задач студенти оволодівають умінням будувати уявну модель комунікативної дії відповідно до особливостей ситуації і партнерів по спілкуванню. Вибирати адекватний певній моделі спосіб практичної дії і реалізувати його в комунікативній діяльності студенти можуть навчитися у процесі участі в рольових іграх: сюжетних, які вимагають тільки імітації відповідних дій, заданих роллю; ситуаційнорольових, які створюють можливості для часткової або повної імпровізації; ділових, у яких професійна діяльність не копіюється, а відтворюється 3 максимальним приближенням до дійсності.

В імітаційній грі студенту задля знаходження дій, які характеризують образ, i відтворення їх, необхідно прийняти позицію даного персонажа, осмислити «його «роль», умови, запропоновані ситуацією, пристосуватися до них, обрати способи комунікативної дії, які адекватно характеризують образ, і здійснювати їх. Для цього слід використовувати акторське «а що коли»- спосіб заглиблення в запропоновані обставини, важіль, який переводить їх із повсякденної дійсності у площину уяви.

Для формування вмінь імпровізації спочатку необхідно використовувати ситуації із заданими параметрами, які потребують самостійного прийняття рішення відповідно до особливостей учасників гри та ситуації. Потім для гри доцільно пропонувати ситуації, структура і межі змісту яких лише частково означені, що створює можливості для свободи комунікативної діяльності.

Організовуючи ділову гру, необхідно виходити з того, що вона, поєднуючи імітаційні вправи, аналіз педагогічних ситуацій, ігрове проектування, дозволяє в умовах варіативності навчального процесу формувати комплекс комунікативних умінь.

Кожне ігрове заняття повинно закінчуватися аналізом, у якому акцентується увага на відповідності комунікативних дій виконавців сюжетній поведінці персонажів. Під час використання ігор необхідно виходити з того, що успішність їх проведення детермінована адекватністю змісту ігрової діяльності знанням, якими студенти оволодівають, особистісною значимістю розв'язуваних проблем, чіткістю визначення мети і завдань, організацією діалогічного спілкування, врахуванням індивідуального комунікативного досвіду студентів у розв'язанні завдань на основі теоретичних знань, а не тільки відповідно до власної позиції, власних бажань.

Під час використання різних видів гри залежно від числа дійових осіб доцільно студентів ділити на групи, щоб вони мали можливість одну і ту ж ситуацію програвати кілька разів.

Практика засвідчує, що значна частина студентів не взмозі адекватно відобразити запропоновані ролі ні у вербальному, ні у пластичному, ні в емоційному аспекті, ні у аспекті створення характеру. В одних студентів відбувається домінування умовностей гри, в інших переважають реальні компоненти, що призводить до витіснення рольової дії, до втрати самої ідеї імітаційної педагогічної гри. У зв'язку з цим відбувається або «тиск ролі», або гравець виходить за іiі межі, не рахується з характеристикою і логікою поведінки інших дійових осіб і оцінює їх не 3 позиції ролі, а 3 власної позиції, що призводить до виникнення труднощів у виборі і прийнятті комунікативно правильних 
рішень. Тому в процесі підготовки до гри ми звертали увагу на усвідомлення iі учасниками необхідності єдності рольової і власної поведінки.

Отже, організація комунікативно спрямованого навчання дозволяє в умовах варіативності навчального спілкування формувати у студентів готовність до комунікативної діяльності.

\section{Література}

1. Андреева Г. М. Общение и оптимизация совместной деятельности / [под редакцией Г. М. Андреевой, Я. Яноушека] - М. : МГУ, 1987. - 302 с. 2. Бабанский Ю. К. Педагогика / Ю.К. Бабанский. - М. : Просвещение, 1998. - С. 345-365. 3. Бодалев А. А. Психологические трудности общения и их преодоление / А.А. Бодалев // Педагогика. - 1992. - № 5,6.- С.77-81. 4. Бутенко Н. Ю. Комунікативні процеси у навчанні: [підручник] / Н. Ю. Бутенко. - К.: КНЕУ, 2004 - 383 с. 5. Волкова Н. П. Професійно-педагогічна комунікація: [навч. посіб.] / Н. П. Волкова. - К. : Академія, 2006. - 256 с. 6. Кан-Калик В. А. Педагогическое творчество / В. А. Кан-Калик, Н. Д. Никандров. - М.: Педагогика,1990. - 144 с. 7. Коломинский Я. Л. Психология общения / Я. Л. Коломинский.- М. : Знание, 1974. - 96 с. 8. Коммуникативность общения в практику работы школы / под ред. И. Е. Пассова. - М. : Просвещение, 1985. - 127 с. 9. Леонтьев А. А. Психология общения / А. А. Леонтьев. - М. : Смысл, 1997. - 365 с. 10. Ломов Б. Ф. Категории общения и деятельности в психологии / Б.Ф. Ломов // Вопросы философии.- 1979. - № 8. - С. 34-47. 11. Максименко С. Д. Технологія спілкування (комунікативна компетентність учителя: сутність $\mathrm{i}$ шляхи формування) / С. Д. Максименко, М. М. Забродський.- К. : Главник, 2005. - 112 с. 12. Петровский А. В. Личность. Деятельность. Коллектив / А. В. Петровский. - М. : Политиздат, 1982. - 255 с. 13. Рыданова И. И. Основы педагогического общения / И. И. Рыданова. - М. : Белорусская наука, 1998. - 319 с.

УДК $366.362: 378$

І. Г. Максименко, кандидат пед. наук, дочент,

Т. Л. Шепеленко,

кандидат пед. наук,

Криворізький економічний інститут

ДВНЗ «Криворізький національний університет»

\section{ТЕОРЕТИКО-МЕТОДИЧНІ ЗАСАДИ ФОРМУВАННЯ КОМУНІКАТИВНИХ УМІНЬ СТУДЕНТІВ У ПРОЦЕСІ ВИВЧЕННЯ ПСИХОЛОГО-ПЕДАГОГІЧНИХ ДИСЦИПЛІН}

Максименко І. Г., Шепеленко Т. Л. Теоретико-методичні засади формування комунікативних умінь студентів у процесі вивчення психолого-педагогічних дисциплін.

У статті обгрунтовуються сутність, зміст, структура комунікативних умінь та визначаються теоретичні і методичні основи їх формування в процесі вивчення психолого-педагогічних дисциплін.

Ключові слова: уміння, навичка, комунікативні вміння, теоретико-методичні засади.

Максименко И. Г., Шепеленко Т. Л. Теоретико-методические основы формирования коммуникативных умений студентов в процессе изучения психолого-педагогических дисциплин

В статье обосновываются сущность, содержание, структура коммуникативных учений, определяются теоретические и методические основы их формирования в процессе изучения психолого-педагогических дисциплин.

Ключевые слова: умение, навык, коммуникативные умения, теоретико-методические основы.

Maksymenko I. G., Shepelenko T. L. Theoretical and methodological foundations of forming of students' communicative skills while learning psychological and pedagogical disciplines.

The article substantiates the nature, content, structure of communicative skills. It also defines theoretical and methodological principles of their formation while learning psychological and pedagogical disciplines.

Key words: skills, communicative skill, theoretical and methodological foundations. 